\title{
Innovative Research on Integrating Chinese Excellent Traditional Culture in Undergraduate Ideological and Political Education of Higher Universities of Traditional Chinese Medicine
}

\author{
Yurong Xuan \\ Department of Ideological and Political Theory, Henan University of Traditional Chinese Medicine, \\ Zhengzhou Henan, 075000, China
}

Key words: Chinese excellent traditional culture, Higher universities of traditional Chinese medicine, Undergraduate, Ideological and political education, Innovation.

\begin{abstract}
Undergraduate ideological and political work of universities of traditional Chinese medicine has certain particularity, different from that of ordinary universities. Hence, multiple factors need considering comprehensively. Under current social background, it is very necessary to reform and innovate in undergraduate ideological and political work of higher universities of traditional Chinese medicine in the process of actively exploring reform and innovation of undergraduate ideological and political education. Starting from Chinese excellent traditional culture, this paper properly analyzes the measures to innovate in undergraduate ideological and political work of universities of traditional Chinese medicine, in the hope of providing favorable support for exerting the effect of undergraduate ideological and political education and facilitating healthy growth of undergraduates.
\end{abstract}

\section{Introduction}

In recent years, higher education has gradually become popular from traditional specialization in the reform development process of higher education. Undergraduates have come common workers cultivated by the state, and have made their contributions to social construction. The popularization of higher education and overall implementation of quality-oriented educational concept propose higher requirements for undergraduates. Universities should not just pay attention to students' knowledge and skill mastery, but also carry out rational ideological guidance for them and comprehensively implement socialist core value in educational practice. On this basis, higher universities of traditional Chinese medicine also should further enhance attention to innovation of undergraduate ideological and political education, utilize the organic connection between traditional Chinese medicine culture and Chinese traditional culture to integrate excellent traditional culture in innovation of undergraduate ideological and political education, give lay to the function of ideological and political education and offer good support for undergraduates' personal development in the process of cultivating high-quality medical talents.

\section{Importance of integrating Chinese excellent traditional culture in undergraduate ideological and political education of higher universities of traditional Chinese medicine}

Chinese excellent traditional culture is the spiritual accumulation which is formed in the process of human long-term participation in social practice, and it is also the aggregation of spirit and thought closely related to human society. To some degree, it represents the soul of a nation and plays a very important role for the development and continuity of a nation. In modern talent training work, Chinese excellent traditional culture also plays a significant role. To integrate excellent traditional culture in undergraduate ideological and political education can well support the exertion of the 
function of undergraduate ideological and political education and all-round innovation of ideological and political work, make sure undergraduates can receive more comprehensive and efficient ideological and political education and provide corresponding guarantee for students' future development. Through analyzing the functions of integrating excellent traditional culture in undergraduate ideological and political education of higher universities of traditional Chinese medicine, it is found that the importance is reflected in the following aspects:

Firstly, excellent traditional culture contributes to implementing the thought of localization of Marxism in China in ideological and political education. The implementation of the thought of localization of Marxism in China is an important content of ideological and political education in higher universities of traditional Chinese medicine. With the help of Chinese excellent traditional culture, the thought of localization of Marxism in China can be better integrated in ideological and political education. Besides, students can better accept this thought. Hence, Chinese excellent traditional culture has an important effect on the thought of localization of Marxism in China. Secondly, Chinese excellent traditional culture can promote popularization of Marxism. In general, practicing Marxist thought in ideological and political education of higher universities of traditional Chinese medicine mainly includes two steps: the masses master the theory, and the theory grasps the masses. Thus, in the ideological and political education process of higher universities of traditional Chinese medicine teach, it is required to learn Chinese excellent traditional culture, inherit the essential thought of excellent traditional culture and carry out positive and healthy ideological guidance for students in order to make students profoundly cognize the knowledge of ideology and politics and the popularization of Marxist theory ${ }^{[1]}$. Finally, to integrate Chinese excellent traditional culture in undergraduate ideological and political education is also an indispensable content of ideological and political education for medical specialty. Chinese excellent traditional culture covers abundant education contents and plays an important role for the students of medical specialty to form correct ideological value. Only when excellent traditional culture is integrated in ideological and political education can positive and healthy ideological education be implemented for the students of medical specialty. Meanwhile, the responsibility sense of students of medical specialty can be enhanced, and future medical development direction can be oriented correctly. Thus in the process of implementing political education for undergraduates in higher universities of traditional Chinese medicine and actively exploring the measures to reform and innovate in ideological and political education, it is very necessary to further enhance attention to Chinese excellent traditional culture, regard Chinese excellent traditional culture as the guiding ideology to guide students' study, guide medical students to form correct outlook on life and value, consciously practice core socialist values with Chinese characteristics in work and life and make certain contributions to the development of China's medical and health services.

\section{Measures to integrate Chinese excellent traditional culture in innovation of undergraduate ideological and political education of higher universities of traditional Chinese medicine}

Chinese excellent traditional culture is closely related to undergraduate ideological and political education of higher universities of traditional Chinese medicine. Hence, in the ideological and political education in the new period, relevant education personnel may actively introduce excellent traditional culture and ideology to guide undergraduate ideological and political education of higher universities of traditional Chinese medicine and indicate the direction for future development of undergraduates.

\section{To actively establish the idea of integrating excellent traditional culture in ideological and political education}

The course of ideology and politics in higher universities of traditional Chinese medicine is one of the fundamental ways to implement ideological and political education for medical students. Comprehensive optimization of ideological and political education cannot be separated from the support of excellent traditional culture. Abundant cultural connotation has been formed in China in 
the 5000-year historical inheritance. In particular, profound cultural thought of traditional Chinese medicine is contained in Chinese traditional culture. If teachers integrate the essence of tradition culture in the process of ideological and political education, a solid foundation can be laid for comprehensive optimization of ideological and political education. In Chinese traditional culture, excellent traditional Chinese medicine culture has certain education function for cultivating medical students. The aims and contents of education keep certain consistency with ideological and political education of traditional Chinese medicine talents. Higher universities of traditional Chinese medicine integrate excellent traditional Chinese medicine culture in the process of cultivating excellent traditional Chinese medicine talents. They not just impart the basic knowledge of traditional Chinese medicine culture, but also correctly guide students to cognize excellent cultural connotation and cultural spirit and supplement talent training work of universities of traditional Chinese medicine. With the integration of excellent traditional culture and the support of traditional Chinese medicine culture, ideological and political education of universities of traditional Chinese medicine can exert its functions to the largest extent. Besides, students' ideological and political quality can be well trained. This can greatly influence students' future career development and really cultivate students into high-quality talents.

\section{To organically combine excellent traditional culture and theoretical teaching of ideology and politics}

The theoretical course of ideology and politics is one of the most important means to implement ideological and political education. During exploring innovative education of ideological and political theory, teachers may properly introduce excellent traditional cultural thoughts, regard excellent traditional cultural thoughts as the guidance to implement ideological and political education and make sure the function of ideological and political education is fully exerted. In the aspect of specific operation, teachers of ideology and politics in higher universities of traditional Chinese medicine can explore the new measures to innovate in ideological and political education from the following perspectives, really integrate excellent traditional culture in ideological and political education and offer favorable support for overall facilitating talent training of universities of traditional Chinese medicine ${ }^{[2]}$.

Firstly, excellent traditional culture and the contents about medical education are integrated in ideological and political education to enhance teaching pertinence and systematicness and promote overall exertion of functions of traditional culture education. For example, the teachers of higher universities of traditional Chinese medicine can properly introduce ancient medical allusions and the stories of celebrities in ideal and faith education and guide students to analyze their dreams and to talk about how to make the dreams come true. In this process, students can not just establish correct ideas, but also accept more visual ideological education and guidance through analyzing the stories about veteran doctors of traditional Chinese medicine and celebrities. Influenced by celebrity effect, students can establish correct ideal and faith and promote their healthy growth.

Secondly, excellent traditional culture is integrated in life outlook and value education of students in the universities of traditional Chinese medicine. The teachers of ideology and politics may analyze undergraduates' ideological characteristics and behavioral characteristics in universities of traditional Chinese medicine in educational practice, combine their specific needs to properly integrate core value concept of traditional culture in life outlook and value education, require students to consciously learn lofty traits of ancestors after class, guide students with traditional cultural allusions, then gradually promote them to establish the correct idea of serving the patients heart and soul, let them really form the ideology of ignoring fame and gain and studying hard and provide corresponding guarantee for them to become qualified doctors in the future.

Thirdly, in terms of life outlook education, teachers may integrate life cognition and life value cognition in excellent traditional culture in education and teaching, let the students correctly treat patients' life value in future work through overall learning the knowledge of ideology and politics, guide students to establish the awareness of life equality and give the correct guidance for their future 
career development ${ }^{[3]}$. Meanwhile, to make the students in higher universities of traditional Chinese medicine form the idea of serving the grass roots through the correct ideological and political education, teachers may introduce some stories about dedication of ancient folk doctors, and let students train consciously at the grass roots, form the profound cognition of serving the grass roots and make contributions to the development of grassroots medical treatment cause in China.

Finally, in professional ethics education, teachers may properly introduce Chinese traditional cultural thoughts, guide students with the traditional moral concept of traditional Chinese medicine, and let students gradually form the ideology of loving medicine course, dedicating themselves to work and serving the people, then consciously practice the idea of dedication, honesty and trustworthiness and make contributions to the socialist cause with Chinese characteristics. In other words, through integrating excellent Chinese traditional culture in undergraduate ideological and political education of universities of traditional Chinese medicine, students can form correct cognition of their social position and social responsibility, which can make sure medical students will not position their life outlook to money and status pursuit, and let them remember their divine duties and then make their contributions.

In conclusion, if the essence of Chinese excellent traditional culture is integrated in ideological and political education, teachers can guide students to form profound cognition for their growth and career development and even to clearly know natural ecological concept, really guide students to grow healthily and gradually cultivate students to become high-quality talents so as to make contributions to the continuous and stable development of medical and health services in China ${ }^{[4]}$.

\section{Methods to integrate Chinese excellent traditional culture in ideological and political education}

Different educational methods can show different educational effects. So, in the process of integrating Chinese excellent traditional culture in ideological and political education, teachers should actively explore different teaching methods, formulate rational integration strategies according to the specific teaching contents, make sure Chinese excellent traditional culture can give full play to its ideological guidance function and provide corresponding guarantee for students' healthy growth ${ }^{[5]}$. In order to ensure the integration effect in the specific teaching practice, teachers should try their best to introduce modern teaching means by combining students' learning needs and interests in modern society such as multimedia assisted teaching and situational teaching, optimize classroom teaching, lead students to participate in social practice and analyze typical cases of traditional Chinese medicine. In this way, students can achieve internalization of excellent traditional culture, accept the guidance of excellent traditional cultural thoughts, really form correct ideological cognition and contribute to the development of medical and health services. For instance, during teaching Outline of Modern History, teachers may play excellent deeds of ancestors to effectively motivate their patriotism and cultivate their consciousness of responsibility. Besides, teachers may let students perform the stories about medical ethics, and make them treat medical ethics with dialectical view and form correct cognition of medical ethics. In the course of Principle of Marxism, the story that Shennong tasted hundreds of herbs and the knowledge of "yin-yang and five elements" mate be introduced. Such knowledge may be combined with material and contradiction in Principle of Marxism so that students can carefully ponder over world outlook and their life outlook, form correct social positioning for traditional Chinese medicine and really become high-quality talents.

\section{Conclusion}

Based on the above analysis, it is very necessary to analyze reform and innovation of ideological and political education in higher universities of traditional Chinese medicine, actively integrate Chinese excellent traditional culture in the reform and innovation process and provide good support for giving play to the effect of undergraduate ideological and political education under the social background of overall promoting reform and development of higher education. Only in this way, ideological and political education in higher universities of traditional Chinese medicine can gain new development effects in the new period and students can be trained to become high-quality medical talents. 


\section{Acknowledgement}

Project: grassroots party building innovation project of Henan institution of higher learning Innovative Research on Party Building work in Higher Universities of Traditional Chinese Medicine under "Dual First-class" Construction, project No.: 2016DJXM056.

\section{References}

[1] Yan Zhenyu, Chinese excellent traditional culture into the path of the ideological and political education, Journal of Jiamusi Vocational Institute, 2015(12):100-101.

[2] Zhang Ruitao, Huo Hongbo, Integration of the Excellent Traditional Culture and the Course of Ideological and Political Theory in Colleges and Universities, Heilongjiang Researches on Higher Education, 2016(7):115-118.

[3] Li Rong, Traditional Moral Personality Theory and Undergraduate Personality Education, Huazhang, 2014(17):141-142.

[4] Wang Huali, Research on Traditional Culture and the Innovation of University Ideological and Political Education, The Science Education Article Collects, 2015(18):6-7.

[5] Yuan Jun, The exploration of the ideological and political education's innovative problems in the perspective of Chinese cultural horizon - case study of "Chinese cultural activity week", Journal of Shandong Agriculture and Engineering University, 2016,33(8):183-184. 